\title{
Financial Mechanism of State Support for Innovative Activity of Business Entities
}

\author{
Zhilkina $Y^{*}$ and D Vodennikov \\ Federal Grid Company of Unified Energy System, Russia
}

\section{ISSN : 2688-836X}

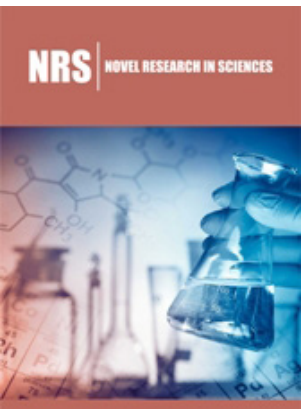

*Corresponding author: Y Zhilkina, Federal Grid Company of Unified Energy System, Russia

Submission:

Published: 㠿September 19, 2019

Volume 2 - Issue 1

How to cite this article: Zhilkina Y, D Vodennikov. Financial Mechanism of State Support for Innovative Activity of Business Entities. Nov Res Sci.2(1). NRS.000529.2019.

DOI: $10.31031 /$ NRS.2019.2.000529

Copyright@ Y Zhilkina, This article is distributed under the terms of the Creative Commons Attribution 4.0 International License, which permits unrestricted use and redistribution provided that the original author and source are credited.

\section{Abstract}

The article considers the key functions of public finance and its role in the economic activity of business entities under market economy. The ways to improve the financial mechanism in enhancing the innovation activity are proposed by the author.

Keywords: Budget; Public finance; Financial policy; Innovation activities

\section{Introduction}

The system of public finance is an important part and an effective tool of contemporary economic policy. Effectiveness of this system largely determines the impact on the economy in general and an innovation activity in particular. The state should build its economic policies to ensure the optimum redistribution of financial resources for the accelerated growth of production as well as quality of life. To provide this it is required to determine the level of state intervention in economic activity of entities and the state's obligation of welfare of its citizens. This approach defines the percentage of the gross national product that needs to be concentrated in financial institutions created by the state. Today, however, other issues arise that require detailed study. This primarily relates to the problems of public finances, improving mechanisms and tools of innovative processes, determining their impact on the regulation of innovation actors in the economy. The purpose of this paper is to determine the role and the functions of public finance in enhancing the innovative activities under transit economy. An important element in transformational economy is the financial system. In this structure limited public financial resources play an important role. The financial system can have a structure that reflects not only the complexity of its organizational method (parallel operation of financial institutions, implementation of market mechanisms etc.), but also a set of caveats and limitations arising from the transformational system itself. Effectiveness of its functioning is affected not only by internal but also by external environment.

Due to the financial system distribution of gross domestic product (GDP), accumulation of financial resources for sustainable economic development is carried out. In transformational economy financial system is an important and effective element of institutional infrastructure. In other words, financial resources act as a component of economic potential. They comprise all available material resources in the state its revenues, expenses and debts. All levels of economic activity are necessary, but the last national one is of particular importance due to function of the state in all economic activities. One of the key functions of the state in transformational economy is the organization of efficient production aimed at improving socioeconomic development. This applies to the sphere of economic activity that requires integrated and effective incentives, regulation and control, taking into account the interests of all economic actors: entrepreneurs and their associations, consumers, employees, local communities, states etc., and the international community (international economic and financial organizations etc.). Only public institutions are able to provide comprehensive and balanced fulfillment of their economic interests, including the use of financial and economic instruments and mechanisms.

Sustainable economic development of the country largely depends on effective functioning of national financial institutions, which activities, in particular, should create conditions for the promotion of innovative business in the country. The analysis shows that effective functioning 
of economic systems in developed countries is determined by the extent of innovative processes, which play the role of locomotive for sustainable economic development. Enhancing innovation in these economies is a crucial factor in their transition from the industrial age to a qualitatively new innovative one. It should be noted that at present for developed countries the main driver of growth is not sustainable financial capital and means of production, but knowledge and new ideas that provide intellectual output, competitive and quality products for which consumers are willing to pay a high price. It is the innovative nature of the economy that provides boosted socioeconomic development and high standards of living. The world experience shows that innovative activity is the main basis for modernization and transformation of the economic system. Under knowledge economy nontraditional industries dominate (where almost all extensive and intensive development factors are exhausted), and a whole new industry is based primarily on the use of new technologies. The introduction of new technologies in industrial production allows a qualitative breakthrough of the national economy into the world markets for goods and services, and the development of high-tech complex stimulates the growth of national economy and creates demand for new and innovative technologies in other industries.

Thus, an important direction of economic policy under transitional system in order to accelerate the socioeconomic development is an effective innovation policy. The strategy of innovative development in economically developed countries of the world can be shaped in different ways. For example, in the US the vast majority of scientific research and experimental development is funded by NGOs (non-governmental organizations) through grants and contracts, which form the basis of innovative processes in the country. Germany in the organization of its innovative process has used the US experience, namely the development of business incubators and science parks (along with the experience of France, the UK and Japan). However, in the late $20^{\text {th }}$ century this country put emphasis on the creation of regional innovation funds, which allowed boosting innovative activity at small and mediumsized enterprises. Japan and the newly industrialized countries of South East Asia in the field of innovations directed their resources on buying promising high-tech innovations and research developments in other countries at the stage of pre-production or laboratory development [1]. In this case, the domestic producers could only arrange the final revision of innovation and run production with further implementation of a new product at a market. The Art. 10 of the Commercial Code of Ukraine declares the main directions of economic policy that directly shape financial and economic mechanisms of innovative activity of economic agents [2]: formation of efficient financial and economic arrangements made within structural and sectoral, investment, depreciation, pricing, budgetary, fiscal, monetary, exchange rate, antitrust and competition policies as well as institutional reforms.

Development of these public finances areas would ensure the optimal balance between the interests of the state and taxpayers (businesses and citizens) in the process of formation and use of various capital funds, which take the form of financial resources of the state. This means that public finances perform a certain number of functions that correspond to the economic model of society, according to its development. However, for the disclosure of internal content of public finance as a socioeconomic category two traditional functions are enough: distribution and control. The first function always reflects the processes of creation, distribution and redistribution of GDP and its transformation into financial resources at every historical stage of economic development of the society and all economic, social and political changes that need pro per funding. The second function is natural for any type of economic system, as financial resources are always limited in the state and require proper control over their distribution and use. Increasing the number of public finance's features, in our opinion, makes it impossible to fully reveal the qualitative characteristics of finance. For this reason, it can be divided into 5 functions of public finance (ensuring expanded reproduction, formation of public consumption funds, maintenance costs of public administration, defense, a national insurance fund). Thus, the functions of finance could hardly be separated from the results achieved in functioning.

Based on the purpose of the study we focus on the first tool of public finance, namely, the provision of expanded reproduction. One of the effective ways of this function realization as international practice shows is the introduction of an innovative development model for the national economic system [3]. This innovative development model of national economy should be based on the existing innovative potential of the country and innovative potential of businesses, as well as entrepreneurial capacity for production innovation. In today's economic studies there are numerous approaches to defining the innovation potential at the macrolevel. Based on the purpose of our study, innovative capacity should be considered as a number of economic resources available in a socioeconomic system for its development at any time.

These resources are shared among the 3 main macro sectors:

\section{Scientific-technical}

2. Educational and

\section{Financial}

And are considered as a part of scientific and technical potential, educational potential and investment potential accordingly. This approach allows considering innovative potential not as all economic resources held by the society, but only that part of resources which can be used at the present level of socioeconomic development, in order to increase production and improve the quality of final product consumption. This methodological approach can adequately reflect not only a particular situation, certain relations in a economic system, but also the laws of their development, and, therefore, assess the effectiveness of the economic system functioning as a whole. Innovative It should be noted that this analysis is based on the macroeconomic approach, but it is necessary to consider the microeconomic approach that is an innovative potential of a single economic entity. Note that the material basis for innovation capacity of enterprises in today's conditions comprises not natural and industrial resources but ideas and innovations based on them. In this case, the innovation potential of a company is to be understood as the ability for more efficient implementation of a particular functional task while maximizing the use of available economic resources. In other 
words, a combination of different types of resources the company needed to implement innovation. Innovative activity of domestic enterprises is characterized in Table 1. In contemporary economic publications of foreign and local researchers the features of state financial incentives for innovative activities are highlighted [4].

Table 1: Innovative activity of domestic enterprises.
Particular attention is paid to the implementation and operation of the mechanisms of innovations financing. The basic mechanisms available in the state are public investment, tax regulations, preferential budget programs, price control, subsidies etc., [5-7].

\begin{tabular}{|c|c|c|c|c|c|}
\hline & 2013 & 2014 & 2015 & 2016 & 2017 \\
\hline Number of innovation active enterprises in the industry & 1397 & 1411 & 1462 & 1679 & 1758 \\
\hline $\begin{array}{l}\text { Number of innovation active enterprises as } \% \text { of the total number of } \\
\text { industrial enterprises }\end{array}$ & 13 & 12.8 & 13.8 & 16.2 & 17.4 \\
\hline Volume of product innovation, thus UAH & 45830161 & 31432252 & 33697574 & 42386723 & 36157725.6 \\
\hline Volume of product innovation as $\%$ of the total industrial production & 5.9 & 4.8 & 3.8 & 3.8 & 3.3 \\
\hline The share of innovative product as $\%$ of GRP & 4.83 & 3.44 & 3.11 & 3.26 & 2.57 \\
\hline
\end{tabular}

Financial mechanisms also include:

1. System of financial planning and execution of plans (program priority areas of innovation implementation, development, project selection and financial security plans, programs and projects etc.).

2. Financial control systems for innovative activities (inspection, supervision, monitoring, evaluation of effectiveness and efficiency, sanctions etc.), system of incentives for innovation (innovative government programs, tax incentives, subsidized loans etc.).

3. Risk insurance for innovative activities (creation of guarantee funds, risk-sharing on public-private partnerships etc.).

Finance subjects of innovative activities are a part of the financial system, which is associated not only with distribution and redistribution processes, but with the formation of GDP in social production sphere as an object of distribution. This feature is evident in the differences of financial relationships system from that one that operates at the macro and mesolevel [8]. The microlevel or the level of the market economy system of financial relationships (for subjects of innovative activity). These relationships arise from:

1. Providing public and private, state (municipal) entities that perform financial and economic activities with registered capital.

2. Formation and distribution of income: gross and net income, profit from ordinary activities, paying taxes and other fees and removal of part of the net income in the budgets of all levels.

3. Contributions to public funds.
4. Budget funding and obtaining loans and grants and so on.

Also, it is the relationships with other entities and financial institutions to invest in securities and revenues from financial investments and corporate rights, relations with credit institutions and insurance companies.

\section{Conclusion}

Under transformational economy the efficiency rate of financing innovations is often high, so the need for further improvement of the financial mechanism of state support for innovation activity under market economy at the macrolevel should be a priority for the economic development of Ukraine. Also, financing subjects of innovative activity is a part of the financial system, which is associated not only with distribution and redistribution processes, but with the creation of GDP in social production sphere as an object of distribution. This feature is evident in the differences of financial relationships system from the one which operates at the macro and mesolevels.

\section{References}

1. Edquist C, Hommen L (2011) Comparing national systems of innovation in Asia and Europe: Theory and Comparative Framework. In: Edquist C, Hommen L, Edward E (Eds.), Small country innovation systems: Globalization, change and policy in Asia and Europe. Published in Chinese by Science Press, Beijing, p. 27.

2. The Commercial Code of Ukraine dated 16.01.2003 № 436-IV.

3. Edquist C, Luukkonen T, Sotarauta M (2009) Broad-based innovation policy, sub-report. In: Evaluation of the finish national innovation system. Full Report, Helsinki, pp. 11-69.

4. Drucker P (1985) Innovation and Entrepreneurship. Harper \& Row, New York, USA, p. 288. 
5. Vasilik OD (2004) Theory of finance: Fundamentals p. 426.

6. Vasilik OD, Pavlyuk KV (2004) Public Finances of Ukraine: Center for Educational Literature p. 608.

7. Karakay Yu V (2009) State regulation of innovation development. Economic Bulletin of NTUU KPI: Collection of Sciences. Work. № 6: 691696.
8. Santo B (1990) Innovation as a means of economic development/per from Hungarian. In: Sazonova BV (Ed.), Total and entry art: Progress p. 295.

For possible submissions Click below: 